Finance and Economics Discussion Series Divisions of Research \& Statistics and Monetary Affairs Federal Reserve Board, Washington, D.C.

\title{
Incentives and Prices for Motor Vehicles: What has been happening in recent years?
}

\section{Carol Corrado, Wendy Dunn, and Maria Otoo}

2006-09

NOTE: Staff working papers in the Finance and Economics Discussion Series (FEDS) are preliminary materials circulated to stimulate discussion and critical comment. The analysis and conclusions set forth are those of the authors and do not indicate concurrence by other members of the research staff or the Board of Governors. References in publications to the Finance and Economics Discussion Series (other than acknowledgement) should be cleared with the author(s) to protect the tentative character of these papers. 


\title{
Incentives and Prices for Motor Vehicles: What has been happening in recent years?
}

\author{
Carol Corrado, Wendy Dunn, and Maria Otoo* \\ Federal Reserve Board \\ Washington, D.C.
}

June 2003

(Revised, January 2006)

\footnotetext{
* We thank Marie Degregorio and Matthew Wilson for their assistance; Robert Schnorbus and Matthew Racho at J.D. Power and Associates for helping us with the data; and Mark Bils, Darrel Cohen, Erwin Diewert, Charles Gilbert, Kathleen Johnson, and Jeremy Rudd for helpful discussions. The views expressed in this paper are those of the authors and should not be attributed to the Board of Governors of the Federal Reserve System or other members of its staff.

This paper was prepared for the SSHRC International Conference on Index Number Theory and Price Measurement, Fairmont Waterfront Hotel, Vancouver, Canada, June 30-July 3, 2004. A preliminary version was given at the CRIW workshop on price measurement at the NBER Summer Institute, Cambridge, Mass., in June 2003.
} 
Incentives and Prices for Motor Vehicles:

What has been happening in recent years?

Carol Corrado, Wendy Dunn, and Maria Otoo

January 2006

\begin{abstract}
$\underline{\text { ABSTRACT }}$
We address the construction of price indexes for consumer vehicles using data collected from a national sample of dealerships. The dataset contains highly disaggregate data on actual sales prices and quantities, along with information on customer cash rebates, financing terms, and much more. Using these data, we are able to capture the actual cash and financing incentives taken by consumers, and we demonstrate that their inclusion in measures of consumer vehicle prices is important. We also document other features of retail vehicle markets that interact and overlap with price measurement issues. In particular, we construct vehicle price indexes under different assumptions about what constitutes a "new" product in moving from one model year to the next. For the period that we study (1999 to 2003), a period during which incentives became more widespread and new model introductions rose, our preferred price index drops faster than the CPI for new vehicles.
\end{abstract}

KEYWORDS: Price indexes, motor vehicles, motor-vehicle financing.

\author{
Carol Corrado \\ Wendy Dunn \\ Maria Otoo \\ Stop 82 \\ Division of Research and Statistics \\ Federal Reserve Board \\ Washington, D.C. 20551
}




\section{Introduction}

Although motor vehicle manufacturers have used incentives to boost consumer sales for some time, direct manufacturer-to-consumer incentives have become both more generous and more widespread in recent years. Using data collected from a large national sample of motor vehicle dealerships, we measure the value of two popular types of vehicle price incentives - cash rebates and reduced-rate financing - and analyze their combined effect on the monthly prices of consumer light vehicles.

Chart 1 shows our estimates of the average values of sales-weighted interest subvention and cash rebates; the data and methods used to develop these estimates are discussed in the next section. Cash rebates are a direct reduction in the retail vehicle price, and the chart plots the value of the rebates used in each period relative to the number of vehicles sold in the period. Reduced-rate financing programs lower the interest rate on financed vehicle purchases, and the chart shows the present discounted value of the reduced payment stream resulting from these programs in each period, again, relative to all vehicles sold in the period. In this paper, we refer to the present discounted value of promotional interest rate reductions as interest rate subvention or, simply, interest subvention.

The two types of incentives have grown in recent years. After varying little, on balance, throughout 2000 and most of 2001, interest subvention shot up in October 2001. In the wake of the attacks of September 11, General Motors announced a program that offered purchasers either zero percent financing for up to sixty months or a cash rebate. This program proved to be immensely popular. In response, most other motor vehicle manufacturers also offered zero percent financing or sweetened their cash rebate programs. Chart 2 illustrates how widely used these incentives have become. By the end of 2003, cash rebates are estimated to have been used in about 57 percent of sales, and interest subvention is estimated to have occurred in a little more than 40 percent of purchases. Most incentive programs allow the consumer to take either the rebate or the special interest rate incentive but not both, and the specific vehicles with programs vary throughout a year.

We believe these developments present challenges for how consumer prices are defined and measured. In its measure of new vehicle prices for the consumer price index (CPI), the Bureau of Labor Statistics (BLS) includes only information on cash rebates, even though the two types of incentives need not be of equal value and both influence the price the consumer actually 
pays for a vehicle. In addition, manufacturers often use the two types interchangeably, and the empirical literature on consumer auto demand has shown that specific models of vehicles are very price elastic (Houthakker and Taylor 1970; Berry, Levinson, and Pakes 1995). Thus, the variation in the type and size of incentives offered with individual models may complicate the construction of a monthly vehicle price index based on a fixed-weighted sample, or subset, of all available models.

In this paper, we work with highly detailed monthly data on prices, quantities and financing terms that allow us to study the workings of retail vehicle markets and to construct vehicle price measures that fully account for interest subvention as well as customer cash rebates. The data we use are based on a sample of dealerships, and, for each dealership, data on sales of all models (and all trim levels of each model) are included. Our results suggest that price measures that include both of these direct manufacturer-to-consumer incentives are necessary for understanding developments in retail vehicle markets in recent years. For example, we calculate monthly matched-model price indexes by model year. These indexes display an interesting pattern in which vehicle prices drop noticeably over the model-year life cycle, in large part because of the marketing incentives paid for by the manufacturers. In another finding, we document an increase in the trend rate of manufacturers' introductions of new and modified vehicles, especially as the size and prevalence of incentives expanded. We also show that newly produced vehicles from different model years are marketed simultaneously for an extended period; that is, the model-year selling period is longer than a calendar year.

The overlap in the model-year selling periods in our data, as well as the generally competitive nature of vehicle markets, suggests that matched-model techniques (Aizcorbe, Corrado, and Doms 2000, 2003) can be used to construct vehicle price indexes that aggregate over model years. Nonetheless, just as the increase in the size and variability of incentive programs presents challenges for the measurement of consumer vehicle prices, so does the increased rate at which makers have been introducing new and modified vehicles.

After introducing and reviewing our data, we establish the findings mentioned earlier and then address the construction of incentive-adjusted price indexes for consumer vehicles that aggregate over model years. Our work is grounded in conventional index number theory and explores the effect on monthly price measures of using different assumptions about what is a new product (or how to "match" prices of vehicles) as one model year ends and the next begins. 
On the one hand, all models could be treated as new with the advent of a new model year; in this case, the recurring model-year price drops are chained together and their cumulative effect over successive years shows through in the aggregate price index. On the other hand, the price pattern could be viewed as a seasonal phenomenon; in this case, the prices are "linked" so that the recurring price drops are offset by recurring increases and little or none of the cumulative effect shows through. Mark Bils (2004) has recently advocated the former approach; results of Pashigian, Bowen, and Gould (1995) suggest that the BLS methods for compiling vehicle prices for the CPI can be regarded, at least in part, as following the latter approach. ${ }^{1}$

Our conclusions are somewhat in the spirit of the findings by Bils (2004), but they are not of the same quantitative size. Using our preferred price concept and matching method, we find that consumer light vehicle prices fell 3-1/4 percent per year, on average, from the end of 1998 to the end of 2003, nearly 2-1/2 percentage points per year faster than the decrease in the CPI for new vehicles. Vehicle prices before adjusting for incentives edge down only $3 / 4$ percent per year, on average; nearly 2 percentage points of the average decline in our preferred incentive-adjusted price index is due to the inclusion of cash rebates, and $3 / 4$ percentage point is attributable to interest subvention.

\section{Data and Concepts}

The data we use in our analysis are from a database called Power Information Network (PIN) Explorer, which is generated by J.D. Power and Associates (JDPA). The database contains information on motor vehicle transactions that is collected from dealerships around the country and uploaded daily from the dealerships' finance and insurance (F\&I) systems. JDPA reviews and checks the data for reporting or clerical errors before making them available to subscribers in PIN Explorer. According to the company, the PIN sample represents 70 percent of the geographical markets in the United States. ${ }^{2}$ Within those markets, JDPA collects data from

\footnotetext{
${ }^{1}$ Pashigian, Bowen, and Gould (1995) showed that the behavior of the not seasonally adjusted car price data in the CPI accords well with what theory would predict for the behavior of prices of a "fashion" good. Price drops for fashion goods over a selling period are regarded as seasonal phenomena. Not all of the price drops for vehicles in the CPI sample are treated as seasonal phenomena; indeed, a portion is treated in what Bils (2004) regards as the appropriate way.

${ }^{2}$ PIN collects data in a number of U.S. markets and in Canada. The U.S. geographic markets as of late 2003 were Boston, New York, Philadelphia, Pittsburgh, Baltimore/Washington DC, Charlotte, Atlanta, Orlando, Tampa, Miami, Houston, Dallas/Fort Worth, Tulsa/Oklahoma City, St. Louis, Indianapolis, Cleveland, Memphis/Nashville, Chicago, Detroit, Minneapolis/St. Paul, Denver, Phoenix, Los Angeles/San Diego, San Francisco/Sacramento, and Seattle/Tacoma/Portland.
} 
roughly one-third of the dealerships and, all told, captures about 20 percent of national retail transactions. $^{3}$

PIN Explorer is incredibly rich and includes detailed information on the price, cost, and type of vehicles sold or in inventory in each period, as well as data on F\&I activity, including the value and terms of the loans received by customers who financed their vehicle purchase through the dealerships. A few demographic variables, such as customer age, are also collected. To examine vehicle prices and incentives, this study uses just a few key price and financing variables in the PIN Explorer database (table 1). Note that the information we use is for both purchased and leased vehicles; the PIN variables for leased transactions are generated in such a way as to make them comparable to series on purchased vehicles. ${ }^{4}$

Our observations are monthly averages of the PIN national level data for new motor vehicles by model and model year from late 1998 through 2003. An example of our primary unit of observation would be the monthly sales (in units) of the 2001 Mercury Sable and the average price (unit value) of the 2001 Mercury Sables sold in a particular month. We do not have access to the data on the individual purchases from which the information in PIN Explorer is constructed, but our model-level-by-model-year database contains about 35,000 monthly observations and consists of essentially the full PIN sample for the period we study.

We refer to the price measures we develop and use in this study as "actual transaction" prices or, simply, "actual" prices. By "actual" price we mean the price that individual consumers actually paid, on average, to purchase a given vehicle in a given month. To generate the actual transaction price, we start with the PIN vehicle price at the level of our unit of observation (model by model year). We then subtract (1) the PIN data on customer cash rebates and (2) our estimate of the value of interest subvention. In the next four sections, we discuss more fully the definition of the PIN vehicle price, the methods used to estimate interest subvention, and the homogeneity of PIN's model-by-model-year unit of observation, and we present summary averages of the data.

\footnotetext{
${ }^{3}$ By manufacturer, the coverage ranges from roughly 15 percent to 25 percent.

${ }^{4}$ For example, for leased transactions, PIN calculates an internal rate of return based on the discounted future cash flows associated with the purchase; cash flows for leases include the residual value, monthly payments, and fees such as points, application costs, and security deposits. This calculation results in a rate that is comparable to the interest rate paid on (financed) purchased vehicles (the annual percentage rate, or APR, as defined in the Federal Reserve Board's Regulation Z).
} 
The PIN vehicle price. The PIN vehicle price incorporates most of the major ways in which retailers influence the price the consumer actually pays for a vehicle. First, it reflects the effect of haggling between the dealer and the consumer. The price the dealer and consumer agree to in a purchase or lease contract is recorded in PIN, and dealer concessions, such as upgrades in accessories or trims provided at no (or below) cost, are captured because the average price for a particular model-by-model-year vehicle in our database is directly affected by the prevalence (or relative absence) of such concessions. Second, the PIN vehicle price reflects the amount a customer receives for a vehicle trade-in. Detailed information on trade-in vehicles is available in PIN, and when a buyer receives a price for a trade-in that is greater or less than its market value, this difference - called an overallowance or underallowance — is recorded and used to adjust the contract price. ${ }^{5}$ Third, PIN records the amount of the "cash-back" that the customer receives from the manufacturer. The cash rebate is a separate field in the F\&I reporting system and the variable is systematically recorded with each transaction in the underlying PIN data.

All told, the PIN vehicle price less the cash rebate is the dollar price, adjusted by the trade-in allowance, that the customer pays for the vehicle and for factory- and dealer-installed accessories and options contracted for at the time of the sale. The PIN vehicle price excludes sales taxes as well as charges for service contracts, financing insurance, and other F\&I products sold by the dealership. Although PIN Explorer has information on the prices customers pay for these products and services, we exclude such products and services from our pricing analysis because they are generally purchased after the transaction price is negotiated. ${ }^{6}$ At times, manufacturers offer buyers free service contracts at no additional cost, but the value of these giveaways is excluded from our price measure. ${ }^{7}$

In constructing the CPI for new motor vehicles, the BLS attempts to capture the actual transaction price, but the resulting BLS measure differs from our PIN-based measure in several important ways. First, the CPI includes sales taxes but excludes an adjustment for the value of vehicle trade-ins. Second, the CPI incorporates an estimated value for service contracts that are

\footnotetext{
${ }^{5}$ As noted in JPDA's Pin Explorer Glossary, when a trade-in is involved in a transaction, the actual price of the vehicle can be masked from the customer. Two identically-equipped vehicles can be sold at the same underlying price to two customers, yet the prices printed on the customers' contracts can appear very different.

${ }^{6}$ For further details on the measures in the PIN database, see PIN Explorer Glossary, J. D. Power and Associates (2003).

${ }^{7}$ A limitation of the data is that PIN Explorer records no information on service contracts that are given away. When a service contract is purchased at a reduced price, however, the value of the contract will appear in PIN along with other related information.
} 
provided at no cost to the consumer but refrains from measuring or recording the value of interest subvention. Third, the CPI is compiled from monthly sample data at the individual transaction level but is not designed to reflect the actual acceptance rate of each incentive program. When consumers are given a choice of either cash back or reduced-rate financing, the BLS subtracts the average value of cash rebates during the preceding thirty days from the sticker price regardless of the incentive program the consumer actually selected. ${ }^{8}$ We estimate that in 2003, the vast majority (more than 70 percent) of manufacturers' incentive promotions allowed consumers to take reduced-rate financing in lieu of, or in addition to, a cash rebate offer. ${ }^{9}$ The remaining programs included only reduced-rate financing.

All told, the BLS methodology probably captures the majority (but certainly not all) of the incentive programs in some fashion. However, the incidence of cash rebates and interest subvention varies notably over time, and the average values of the two types of incentives are usually unequal. Although the PIN data we use are not at the individual transactions level, our PIN-based prices will reflect the actual monthly variation in the size and incidence of incentives shown in charts 1 and 2. We thus believe that the PIN vehicle price less the cash rebate is a highly accurate measure. Indeed, the adjustment for trade-in allowances and the availability of related statistics on leasing and financing suggests that the PIN data have certain advantages over the CPI's sample data for studying and measuring consumer vehicle prices.

Interest subvention. Interest subvention occurs when a consumer receives an interest rate for a vehicle purchase through a manufacturer's financial services company (GMAC, Ford Financial, Honda Financial Services, and so on) that is lower than the interest rate that could have been obtained elsewhere. Although interest subvention is a direct manufacturer-toconsumer incentive that affects the price the consumer actually pays for a vehicle, unlike customer cash rebates, interest subvention cannot be observed directly and must be estimated.

To estimate interest subvention, we use the PIN interest rate received by customers who financed or leased new vehicles through dealerships and compute the present value of the difference between the monthly payment stream under this rate and the stream under an

\footnotetext{
${ }^{8}$ To estimate the CPI for new motor vehicles, the BLS begins with the vehicle's sticker price. It then adjusts the sticker price to arrive at a transactions price. According to the BLS Handbook of Methods (page 29), "When pricing new vehicles, BLS economic assistants obtain separately all the components of the sticker price. This includes the base price and the price for options, dealer preparation, transportation, etc." Since 1998, the CPI has excluded the line item, "automobile finance charges," which was separate from the index for new vehicles.

${ }^{9}$ The calculation is based on incentive programs offered by the six largest-selling manufacturers in the United States: General Motors, Ford, Chrysler, Toyota, Honda, and Nissan.
} 
alternative rate the buyer would pay at an outside, independent lending source. The difference between the two payment streams is discounted to the present at a constant rate of 4 percent. The alternative rate is determined from information published in the Federal Reserve's Survey of Consumer Finances (SCF) and from the new car loan rate published in the Federal Reserve's G.19 monthly statistical release, Consumer Credit.

To compute the actual payment stream, we need information on the loan amount, loan length, and interest rate that consumers actually receive. As indicated in table 1, PIN provides these measures. Unfortunately, the PIN measures that we have are for all customers who finance (or lease) their vehicle through dealerships, whereas ideally we would like to have measures that exclude the transactions in which the lender (or lessor) is not owned by the manufacturer. ${ }^{10}$ However, we believe that this distinction is of little practical importance because the overall percentage of dealer-financed transactions in which the lender is not owned by the manufacturer is relatively small. The data from PIN for 2002 and 2003 show that, on average, less than 15 percent of dealer-financed sales used independent lenders in those years. ${ }^{11}$

To compute the alternative monthly payment stream, we need a measure for the alternative rate that the buyer would pay at an outside, independent lending source. The alternative rate that we start with is the forty-eight-month commercial motor vehicle loan rate issued by the Federal Reserve Board. This rate is obtained from a survey of commercial banks in which respondents are asked to report their "most common" interest rate for new forty-eightmonth motor vehicle loans; the published aggregate is the average of these reported rates. A benefit of using this rate is its ready availability. However, a downside is that using it assumes that all consumers face the same alternative interest rate regardless of creditworthiness.

The creditworthiness of a potential buyer depends on a variety of factors. However, age (the primary buyer characteristic that we have available) is useful in assessing the interest rate that a buyer is likely to receive. Data from the 2001 SCF indicate that, as a respondent's age

\footnotetext{
${ }^{10}$ For ease of exposition, we will omit references to lease transactions in the discussion that follows. Of course, the subvention estimates we develop fully capture the effects of lease promotions ("no down payment", "no lease-end fees", and so on) if such promotions actually lower the lessor's implied rate of return on a lease transaction.

${ }^{11}$ Nonetheless, if independent financing through dealerships is a significant source of interest subvention, our measure will overstate the manufacturer-to-consumer concept that we want. We believe this possibility to be highly unlikely, however. When a customer fills out a loan application at a dealership, often the dealership submits the application to a number of lenders. If an independent lender accepts the customer's loan application, a wholesale rate is quoted to the dealership. The dealership may then quote a higher rate to the customer, and this rate becomes the observed retail rate (if the transaction is consummated). The spread between wholesale and retail rates has traditionally been an important source of dealership revenue.
} 
increases, the average interest rate on new vehicle loans drops steadily (table 2). In our data, customer age varies substantially across models, and this variation removes any illusion of buyer homogeneity.

Next, we report the results of regressions that use a variety of series to explain the interest rate that SCF respondents received for new vehicle loans (table 3). All of the loans in the estimation originated in the years 1999 through 2001. As shown in column 1 of the table, the coefficient on the average age of the respondent is negative and statistically significant. Regressions in columns 2 and 3 include income and wages, respectively, as well as other variables. In addition to age, home ownership and educational attainment are important explanatory variables for the new vehicle loan rate that SCF respondents received. When these additional variables are included, the coefficient on age decreases in size but remains statistically significant. $^{12}$

We used the coefficient estimate in column 1 to adjust the alternative interest rate in our calculations by the average customer age for each model in each month. For models with an average customer age equal to the mean of the whole sample, the alternative interest rate is the forty-eight-month commercial bank rate. For models with a customer age lower than the overall sales-weighted mean (44-1/2 years), the alternative rate was increased 0.05 percentage point for each year below the mean. Thus, a model with a mean customer age of 18 years would have an alternative interest rate roughly 1-1/4 percentage points higher than would a model with a mean customer age of 44-1/2 years. Models with average customer ages greater than the overall average would have lower rates.

Another assumption in using the forty-eight-month bank rate as an alternative rate is that it serves as a reasonable proxy for rates that buyers could have received from other lenders. In PIN, loans financed through outside lenders are recorded as "cash" transactions, and no information is collected on the terms of these loans. We again turned to the SCF to obtain additional information. Table 3 also shows regression results that control for lending source. We use dummy variables for loans obtained from captive finance companies, credit unions, and finance companies. The results, shown in column 4, are reported relative to an alternative in which loans are obtained from commercial banks. As seen in the coefficient estimates, rates on

\footnotetext{
${ }^{12}$ Note that the coefficients on income and wages are insignificant when home ownership and educational attainment are included in the regressions.
} 
loans from captive finance companies and credit unions were each more than 1 percentage point less than those on loans at commercial banks. In contrast, loans from finance companies carried interest rates that were about 1-1/2 percentage point higher than those from commercial banks. ${ }^{13}$

The results in column 4 suggest that the commercial bank rate that we use in our analysis may overstate the alternative rate for customers who otherwise would have used a credit union. On the other hand, it may understate the alternative rate for customers of finance companies. Nevertheless, given the limited demographic data available in PIN Explorer, we believe that the aggregate forty-eight-month commercial bank rate that uses customer age to adjust for creditworthiness is a reasonable proxy for the alternative lending rate that is needed to estimate interest subvention.

Unit of observation. As indicated earlier, our primary unit of observation is by model and model year, but for many vehicles our PIN model-level observations are more detailed than is suggested by the term "model." Moreover, PIN Explorer contains what it calls "trim level" observations that are even more detailed than its model-level observations that we use. Table 4 provides examples of our model-level detail as well as our nomenclature. For example, in our sample, we include the model Buick LeSabre. The trim-level appellation is Buick LeSabre Limited. However, for some models in our sample (for example, the Mercedes ML320 or the BMW 325xi), no further level of detail is available. Thus, PIN covers these models (or "series" of cars) at essentially the trim level.

We next compare the model-level observations available in the data issued by Ward's Communications, a leading source of information on the motor vehicle industry, with the modellevel observations available in PIN. We use the model year 2002 for illustration. In the Ward's data, 16 models accounted for the top one-third of all light vehicle sales. The middle one-third was accounted for by another 42 models and the bottom one-third by more than 200 others. By contrast, 34 PIN models accounted for the top one-third of sales, a number more than twice as large as the corresponding Ward's number, and PIN's model count for the second one-third was also much larger with a count of 65. Besides PIN's distinctions for "series" of cars, such as the BMW and Mercedes vehicles noted earlier, much of the additional stratification available in PIN

\footnotetext{
${ }^{13}$ The coefficient estimates in column 4 changed little when the home ownership and educational attainment variables were added to the regression.
} 
models relative to Ward's models occurs in "lines" of popular light trucks and sport-utility vehicles, or SUVs (Ford F-150, Ford F-250, Silverado 1500, Silverado 2500, and so on).

PIN's trim-level observations are much more granular than their model-level data. In our work to construct vehicle price indexes from PIN model-level data, we exploit information from these highly detailed data. We do not work directly with the trim-level observations because the transactions count for many of the trims in the bottom third of sales is extremely thin. In addition, the information on trim levels that we have (in terms of the types of variables) is limited before January 2001. ${ }^{14}$

Summary averages of the data. We calculate the aggregate average values of our incentive and price measures for each year from 1999 to 2003 and for the period as a whole; the data are sales-weighted (table 5). We estimate that direct manufacturer-to-consumer incentives on new vehicle purchases averaged nearly $\$ 1,500$ from 1999 to 2003 and that interest subvention and cash rebates were about equal in value, on average. The average value of cash rebates skyrocketed over the period, however, and the average value of incentives in 2003 was nearly triple that in 1999.

The average actual price that consumers paid for a vehicle was about $\$ 24,000$ and rose noticeably between 1999 and 2003. By 2003, the overall average selling price (ASP) was $\$ 25,000$, and the ASP for trucks was more than $\$ 4,000$ larger than that for cars. From 1999 to 2003 (on a December to December basis, not shown in the table), the overall ASP rose 2-1/2 percent per year. Excluding incentives, the ASP of vehicles rose 3-1/2 percent per year.

With regard to financing during the 1999 to 2003 period, the average interest rate received for new vehicle loans peaked in 2000 at 8.2 percent but fell subsequently to an average of 5.4 percent in 2003. Over the same period, the average loan term for dealer-financed loans rose from about four years to nearly five years. Low interest rates and longer terms allowed consumers to keep monthly payments low even as the average amount financed rose. From 1999 to 2003 , the average amount financed climbed almost 13 percent, while the average actual price paid for a new vehicle increased 6-3/4 percent. ${ }^{15}$

\footnotetext{
${ }^{14}$ The second limitation refers to the data from PIN Explorer that are available to us; this is not an inherent limitation of the information collected by JPDA for inclusion in PIN.

${ }^{15}$ This differential does not necessarily reflect an increase in the loan-to-value ratio. Consumers may chose to finance sales taxes and the F\&I products (service contracts, insurance) or additional items (fabric protector, paint sealants) purchased from the dealership, and the prices (or quantities) of these items may have increased more than the vehicle price during this period.
} 


\section{Retail Vehicle Markets in Recent Years}

In addition to incentives becoming more generous and widespread, other developments in retail vehicle markets in recent years interact and overlap with the measurement of consumer vehicle purchase prices.

New model introductions. We report the number of PIN models by model year for the model years 1998 to 2004 (table 6). All told, our database has observations on more than 500 unique PIN models, and, on average, about 260 of the models were sold in adjacent model years. ${ }^{16}$ We also show the number of PIN models that were newly introduced in each year as well as statistics that we derived on continuing models for which major redesigns were made or for which new trim levels became available (without major redesigns). We define a major redesign as a platform change and a new trim level as a name change in PIN's trim-level observations. ${ }^{17}$ In 2001, the number of new models in PIN Explorer jumped to nearly 60 and has since remained elevated. The count of redesigns showed no trend during the period we study, but the number of new trims also jumped in 2001 and has remained at what looks to be a relatively high rate.

The rise in new model introductions that began with the 2001 model year is confirmed by both Ward's model-year statistics (see last column of table 6) and Ward's monthly sales data on the number of unique models sold, shown in chart 3 to display a longer perspective. As illustrated in the chart, the number of models sold changed little from 1995 to 1999, but rose dramatically beginning in 2000 with the introduction of 2001 model year vehicles. Many of the newly introduced models were new varieties of SUVs, which are profitable and popular types of light trucks. The new trim levels were also disproportionately concentrated among SUVs and consisted of upgrades in interior finishing and electronics (such as navigation systems), larger engines, or other driving and safety features.

\footnotetext{
${ }^{16}$ The database that we construct from the raw PIN data uses 490 PIN models rather than the 506 PIN models available to us because of the need to drop 16 models with missing or problematic observations. The dropped models account for an extremely small, negligible portion of total sales.

${ }^{17}$ A platform is the basic structure of a vehicle; we used Ward's data on vehicle platforms by model year to identify models that had been through major redesigns. For PIN models more disaggregate than Ward's models, we used information from Internet sources (new vehicle reviews and summary articles on vehicle redesigns) to make the identification. We also used Internet sources to verify the accuracy of trim change counts for models with two or more name changes.
} 
Our data are thus capturing an important development in vehicle markets in recent years - namely, that manufacturers noticeably expanded the number of models and trims that they produced and marketed. We believe PIN Explorer is especially well suited to pick up the price implications of this development. Because the PIN data are collected from a sample of dealerships, information on sales of new and modified model sales are recorded in the system at the time of introduction. But price collectors (who select and track specific vehicles to obtain price information) or compilers of model-level list prices (who must pick a particular trim level for each model) may be challenged by having to choose representative vehicles during a period of rapid change.

Sales over the model year. We report information on the number of continuing, entering, and exiting models, by quarter within each model year (table 7). These figures highlight several key within-model-year properties of vehicle markets. First, as indicated by the row labeled "Total continuing" models, a significant portion of the total number of marketed models in any given period is available for computing a price change. Second, as seen in the rows that break out continuing models, by model year, the new vehicles available for sale in each period are from more than one model-year vintage; indeed, in many instances, vehicles from three different vintages are available for sale in the same quarter. Third, as shown in the row labeled "Entering," most new vehicle vintages are introduced in the third quarter, a reflection of the well-known model-year changeover pattern in production. By contrast, the clearing of older vehicles from dealers' lots, shown in the row labeled "Exiting," occurs relatively smoothly over the calendar year.

All told, the quarterly data in the table illustrate that newly produced vehicles of a given model year are almost always marketed simultaneously with newly produced vehicles of an adjacent model year. Chart 4 shows this pattern in more detail by plotting monthly expenditure shares by model year over time. As can be seen in the chart, the sales cycle for each model-year vintage typically runs for about eighteen months (from July through December of the following year) and, consequently, it overlaps with the sales cycle of vehicles in preceding and subsequent model years for a considerable time. Shifts in purchases of new model-year vehicles occur most often during the late summer and early fall (August, September, and October). Unlike the abrupt 
model-year changeover in production, the transition in spending from one model year to the next occurs relatively more smoothly. ${ }^{18}$

The relatively smooth pattern of initial sales of new model-year vehicles in the late summer and early fall differs from the pattern that existed many years ago. We lack highfrequency data on sales by model year for earlier periods to confirm the exact timing and nature of the shift, but we can observe the evolution of the seasonal factor for aggregate monthly sales from the late 1970 s to the present. ${ }^{19}$ Seasonal factors for recent years lead us to expect aboveaverage sales in July and August and average or slightly below-average sales in September and October. Factors for the late 1970s for these months expected sales to be substantially aboveaverage in October and below-average otherwise. By segment, the results for domestic autos are the most striking. The October seasonal factor for domestic auto sales was 112 in 1977 but gradually fell over the years and was 91 in 2003.

\section{Price Indexes for Consumer Vehicles}

The availability of price and quantity information for a nontrivial number of essentially identical products whose prices are available in adjacent monthly periods suggests that matchedmodel techniques can be used to construct price indexes for consumer vehicles. A long, distinguished literature has addressed the use of a hedonic approach to measure quality-adjusted prices for motor vehicles (Griliches 1961, Triplett 1969, Gordon 1990, among others), but these studies had to rely almost exclusively on annual data on list prices at the start of each model year. By contrast, we are able to work with data that conform to the demands of conventional index number theory-very detailed, comprehensive monthly data on actual prices and quantities.

The matched-model Törnqvist price index, which is grounded in conventional index number theory, is a weighted geometric mean of price ratios of homogeneous items, denoted by the subscript " $\mathrm{j}$ " that uses an average of each item's revenue share in the two periods as weights. In logs, the aggregate price change from $t-1$ to $t$ is expressed as follows:

\footnotetext{
18 These different production and spending patterns by model year show through in the composition and age of dealers' inventory by model year. The automaker's inventory control problem and its implications for manufacturers' pricing decisions are explored in Copeland, Dunn, and Hall (2005).

${ }^{19} \mathrm{We}$ wish to thank our colleague Dan Vine for pointing us in this direction.
} 
$\ln P_{t}-\ln P_{t-1}=\sum_{j \in \mathrm{M}_{t / t-1}} S_{j, t}\left(\ln P_{j, t}-\ln P_{j, t-1}\right)$,

where

$S_{j, t}=1 / 2\left[P Q_{j, t} / \sum_{j \in \mathrm{M}_{t / t-1}} P Q_{j, t}+P Q_{j . t-1} / \sum_{j \in \mathrm{M} t / t-1} P Q_{j . t-1}\right]$

$t=1, \ldots . \mathrm{T}$

Summation over matched models is denoted as $\sum_{j \in \mathrm{M}_{t / t-1}}$, where $\mathrm{M}_{t}$ is the set of unique goods produced or sold in each period and $\mathrm{M}_{t / t-1}$, (that is, $\mathrm{M}_{t} \cap \mathrm{M}_{t-1}$ ) is the set of goods produced or sold in adjacent periods.

When the results of (1), as well as those of the closely related Fisher formula, are chained together over $\mathrm{T}$ periods, the price index is exact for periods before and after changes in the composition of $\mathrm{M}_{t / t-1}$ (Diewert 1987). Although this procedure makes no special allowance for entry and exit, if entering and exiting items are essentially perfect substitutes for continuing items (and if we make certain assumptions about consumer preferences), the resulting aggregate price index approximates an exact index for all periods, not just those in which there are no compositional changes in $\mathrm{M}_{t / t-1}$ (Feenstra 1994). Accordingly, we use (1) both to observe the pattern of prices by model year and to construct an aggregate price index across all vehicles in the sample.

Price indexes by model year. We assume that the mix of sales among trims exhibits no trend over a model year and that the PIN models (our unit of observation) are essentially homogeneous across monthly observations. Under these conditions, our model-level price data (unit values) are the appropriate data for measuring aggregate price change (Balk 1998), and we can compute (1) from the monthly PIN model-level data for each model year (see table 7).

In table 8, we summarize the model-year price declines by reporting annualized fivequarter changes (from the third quarter of the introductory year to the fourth quarter of the following year) for various price measures and for subcategories grouped by nameplate. The results illustrate clearly that significant and broad-based declines in vehicle prices occurred over all model years in the sample. As noted earlier, a potential explanation for these recurring price declines is that more fashion-oriented, or price-inelastic, shoppers purchase vehicles early in the model year, while more price sensitive consumers wait until later in the model year. If this were the case, we would expect to see a similar declining pattern in the average buyer age, our best 
proxy for income. However, we found that the aggregate average buyer age did not vary systematically over the model year.

By comparing the different price measures, one can see that the magnitude of the drop in vehicle prices over the model year increases as the price concept is broadened to capture all forms of incentives. Our measure of the actual price, which nets out both cash rebates and interest subvention, decreases, on average, at an annual rate of 6.1 percent over the model life cycle. By contrast, the model-year price declines before incentives average just 2.4 percent over the same period. The within-year patterns of these indexes are displayed in chart 5, in which one can see that the drop in the actual price is often steeper at the beginning and at the end of the model year cycle. The indexes also show that the within-year price declines accelerated over the sample period and that the difference between prices before and after incentives widened as well.

Looking at the effects of incentives for the various nameplate categories, one can see that the Big Three (General Motors, Ford, and Chrysler) consistently use cash rebates to reduce prices. These rebates increased at an average annual rate of 3.6 percent over the model year, and in model year 2003 they jumped more than 8 percent. At the large Japanese firms (Toyota, Honda, and Nissan), cash rebates are not nearly as popular as they are at the Big Three. Only in the most recent model year in the sample did these firms begin to use cash rebates more intensively.

Beginning in the 2000 model year, financing incentives also became more prevalent, particularly for the Big Three nameplates. When General Motors offered zero-interest finance rates on most of its models after the terrorist attacks on September 11, 2001, the value of interest subvention increased sharply, contributing 3.2 percentage points to the decline in actual prices over the model year. Although the increase in interest subvention in 2001 was most pronounced for the Big Three nameplates, a pickup in these incentives for the large Japanese nameplates was also noticeable. Expenditure patterns shifted dramatically over this period, as a large share of consumers substituted away from cash rebates and accepted the financing incentives (see chart 2). This pattern is especially apparent in the divergence between the broadest price measure and the measure that just excludes cash rebates. These two price measures differ most noticeably from 2001 to 2003.

Next, we report changes in the model-year price indexes for cars versus trucks and for eight vehicle market segments using our preferred price concept (table 9). One can see that, for 
the most part, prices for the various vehicle segments tend to decline at about the same rate over the model year once both cash rebates and interest subvention are taken into account. One notable exception, however, is full-size cars, which appear to have much steeper price declines over the model year than do other vehicle segments. The difference mainly reflects more generous incentives for the segment, as prices before incentives fall at about the same rate for full-size cars as for cars in other vehicle segments. With price declines averaging just 5.6 percent, the indexes for luxury cars exhibit the smallest price reductions over the model year, and incentives for this segment contribute just 0.6 percentage points to the overall decrease.

Finally, we report changes in the model-year actual prices disaggregated by models that were new or major redesigns versus models that continued from the previous year with no major change (table 10). In a given model year, the grouping of "new" models makes up between 15 percent and 25 percent of the total number of unique models sold (see the second and fourth columns of table 5 relative to the first column of the table). Differences in price movements between these two categories will have implications for aggregate price indexes over time because, as will be described shortly, they represent one view of which models are new goods and which are continuing goods. Nevertheless, as can be seen in the table, although the value of incentives increases more for models that are not new or redesigned, the overall price declines by model year are fairly similar for both categories.

Aggregate consumer vehicle prices. The richness of our data suggests that an aggregate price index — not just price indexes by model year — can also be computed using (1). The resulting measures, however, depend critically on the interpretation of what defines a unique good. In particular, the results depend on which vehicles can and cannot be considered similar across model years or, put differently, they rely on how the observations in our dataset should be "matched" in (1) when moving from one model year to the next.

To illustrate this problem, we consider three alternatives for "matching": First, we assume that vehicles of different model years have virtually identical features until they undergo a major redesign. In this situation, we match adjacent observations for a given model, irrespective of model year, except in cases in which the vehicle has been through a major redesign. Once redesigned, these model-year vehicles are treated as separate goods in (1), along with the vehicles that newly enter the market in a given model year. Second, we treat both redesigned vehicles and vehicles with new trim options as new goods; otherwise, the price index 
is compiled according to the same procedure as used in the first alternative. As noted earlier, manufacturers greatly expanded the trim options they offered on existing models during the sample period. In the case of the second alternative, therefore, the number of vehicles treated as entering goods in (1) is more than double the number under the first alternative. Finally, we treat all models at the close of one season versus those at the beginning of another as separate goods in (1). This third alternative is consistent with the view that, with every new model year, the physical characteristics of a vehicle change sufficiently so that we can only match adjacentmonth prices for a given model in a given model year, in which case the number of new goods in (1) is equal to the number of vehicles in each model year.

We calculate the aggregate indexes that result from the three matching assumptions and for the various price measures (table 11). Regarding the results for the actual price, the index that treats all models as unique goods drops most sharply over time: The twelve-month changes drop 6 percent, on average, over the five-year period. This large cumulative drop essentially reflects the chaining together over time of the recurring within-year model-year price declines shown earlier. ${ }^{20}$ Moreover, under this matching assumption, the price declines appear to have accelerated in recent years, registering an estimated decline of nearly 8 percent over 2003. By contrast, the matching assumption that treats only entering models and redesigned models as separate goods results in a price index that falls just slightly more than 1 percent per year, on average, and the declines do not appear to have accelerated in recent years.

The matching assumption that treats both redesigned models and model-year vehicles with trim changes as new products results in an average aggregate price decline that falls in between the rates implied by the two other indexes-actual consumer vehicle prices drop 3-1/4 percent per year, on average, when we use this intermediate assumption. Because there are many examples of models and trims that, from one model year to the next, are virtually identical - except for their model-year designations - one could argue that the intermediate assumption yields the most appropriate price index. Certainly, in view of the results presented in table 6, we would have difficultly arguing that only new and redesigned models (the first alternative) are all that are "new" as one model year ends and the next begins.

\footnotetext{
${ }^{20}$ Indeed, indexes calculated under the third matching assumption are equivalent to indexes calculated using modelyear expenditure shares (previously shown in chart 4) to aggregate the model-year matched-model price indexes (previously shown in chart 5) according to equation (1).
} 
One could also argue, however, that because of the interaction between new and used vehicle markets, and because the model year is an easily observable product characteristic that is strongly correlated with the age of a vehicle, the treatment of all model-year vehicles as separate goods (the third alternative) may best reflect the underlying consumer preferences that drive prices downward over the model year. However, we believe this line of reasoning suggests that recurring price declines are seasonal (related to obsolescence, the loss of "newness") rather than reflecting persistent declines in the actual price of new vehicles. ${ }^{21}$

A logical implication of the view that recurring price declines are seasonal is to formally treat vehicles as "weakly seasonal" commodities and to use one of the indexes suggested by Diewert (1998, 1999; see also Balk 1980) for these types of goods. Applied to vehicles, these indexes would match the price of a given model year vehicle in a month with the year-earlier price of its year-earlier vintage. We investigated this approach and found that prices dropped less than under our three primary alternatives, but were nonetheless very close to those calculated using the first alternative. Note that seasonal index numbers exclude information on the prices and market shares of entering (and redesigned) models until one year after their introduction (or change). We believe the very high rate of new model introductions over the period we study presents problems for using the seasonal index number approach to measure vehicle prices.

Notably, under all three of our primary matching assumptions, the index for the actual vehicle price falls more rapidly than would be implied by the CPI for new vehicles (shown at the bottom of the table). Arguably, the CPI concept falls somewhere between our actual price and the PIN price after cash rebate (discussed earlier), and the CPI "matching" method is probably closest to our first alternative (Pashigian, Bowen, and Gould 1995; Bils 2004). This suggests that the differences between our preferred approach (the second matching alternative applied to the actual price) and the CPI approach stem largely from differences in methods. Indeed, the CPI measure of price change is between the results for the first matching method applied to the actual price and those for this same method applied to the PIN price after cash rebate.

Implications for quality change. Our new estimates of vehicle price change have implications for the associated measures of quality improvement and productivity that took place in recent years. In the bottom half of table 11, we report the implied measures of quality change

\footnotetext{
${ }^{21}$ Obsolescence is defined as the decline in the price of a newly produced asset (or a price index for a cohort of assets) in the presence of a new vintage of the asset, a definition and terminology drawn from the literature on economic depreciation. See Diewert (2005) for a recent review of this literature.
} 
for each of the alternative matching assumptions and price measures. These rates are derived by subtracting the constant-quality price change from the total change in vehicle price, as measured by the change in the average selling price, or ASP. ${ }^{22}$ Although the size and variation in the resulting estimates of quality change are substantial, when we base our calculation on the actual price and the second matching assumption (our preferred measure), we find that the average annual pace of quality improvement from 1999 to 2003 was nearly 6 percent per year.

Our estimates of quality change can be compared with those that Bils (2004) constructed from micro CPI data. In that paper, the author argues that, contrary to current BLS methods used for constructing price indexes for most goods, forced product substitutions should be treated the same way that scheduled substitutions are treated--with price changes across substituted models viewed as quality upgrades. ${ }^{23}$ This suggestion is closest to following our matching assumption that treats every model-year vehicle as a new product. For motor vehicles, Bils finds that prices for matched models declined an average of 3.3 percent per year from 1988 to 2003, a result that when combined with the 4.0 percent increase in unit prices over the same period, implies that quality advanced 7.3 percent per year. This figure is much faster than the 2.9 percent rate implied by the current BLS methodology for motor vehicle price indexes.

As noted earlier, using our data on actual prices, we find that the matched-model index that treats every model-year vehicle as a new product declined by nearly 6 percent per year, on average, from 1999 to 2003. Coupled with the 2-1/2 percent increase in average selling prices, this result implies that measured quality increased nearly 8-1/2 percent per year, a figure very close to Bils's estimate for the longer sample period. If the measure of price less cash rebate measure is used, then our estimate of quality change is nearly identical to that derived by Bils.

\section{Conclusion}

In this paper we use a rich data set of monthly sales, transaction prices, and financing terms to document several empirical observations on prices for motor vehicles. First, we show that financing incentives play an integral role in understanding recent movements in aggregate

\footnotetext{
${ }^{22}$ These changes, which are shown in the middle panel of the table, were calculated from the data on ASPs in dollars (shown on table 5).

${ }^{23}$ At regular sample rotations, the BLS draws a new sample of stores and products within a geographic area to better reflect current consumer spending. Bils (2004) refers to these as scheduled substitutions. Forced substitutions occur when a store stops selling a particular product that is being priced, and the BLS agent substitutes another model of that brand or of a similar product.
} 
vehicle prices. We also find that multiple vintages of the same models are often sold simultaneously in retail vehicle markets, a practice that presents challenges as well as opportunities for measuring vehicle purchase prices. We examine within-model-year price movements and find that vehicle prices drop rapidly in the months after their introduction, often in large part through the use of direct manufacturer-to-consumer incentives. Finally, we consider the construction of a price index that uses matched-model techniques to aggregate over model years.

The results of using a conventional index number approach to measure vehicle prices depend crucially on which vehicles can and cannot be considered similar across model years. Our preferred approach, which regards major redesigns and new trims as new (or separate) goods, yields a price index for consumer vehicles that drops faster than the decline shown by the CPI for the same period. We attribute this result to two developments - both relatively recentthat we believe are incorporated more accurately in the price measure constructed using our data and our approach. First, the rate at which manufacturers introduced new and modified models increased dramatically beginning in 2000, and the CPI may have been slow to adapt to the change, in effect treating many of the popular, expanded trim options as price increases. Second, the value and incidence of interest subvention increased noticeably in late 2001 and in 2002 and likely is not fully reflected in the CPI. All told, we find that the pace of quality improvement in consumer vehicles averaged 6 percent per year from 1999 to 2003, a pace twice that implied by official estimates. 


\section{References}

Aizcorbe, Ana, Carol Corrado, and Mark Doms (2000). "Constructing Price and Quantity Indexes for High Technology Goods," paper presented at the CRIW workshop, National Bureau of Economic Research Summer Institute 2000, Cambridge, Mass., www.nber.org/ confer/2000/si2000/doms.pdf.

Aizcorbe, Ana, Carol Corrado, and Mark Doms (2003). "When Do Matched-Model and Hedonic Techniques Yield Similar Measures?” Working Paper Series 2003-13. San Francisco: Federal Reserve Bank of San Francisco (June).

Balk, B.M. (1980). "A Method for Constructing Price Indices for Seasonal Commodities," Journal of the Royal Statistical Society, Series A (General), vol. 143 (1), pp. 68-75.

Balk, B.M. (1998). “On the Use of Unit Value Indices as Consumer Price Subindices,” in Walter Lane, ed., Proceedings of the Fourth Meeting of the International Working Group on Price Indices. Washington: U.S. Department of Labor, Bureau of Labor Statistics, pp. 112-20.

Berry, Steven, James Levinsohn, and Ariel Pakes (1995). “Automobile Prices in Market Equilibrium," Econometrica, vol. 63 (July), pp. 841-90.

Bils, Mark (2004). "Measuring Growth from Better and Better Goods," NBER Working Paper Series 10606. Cambridge, Mass.: National Bureau of Economic Research, July.

Bureau of Labor Statistics (1997). BLS Handbook of Methods. Washington: U.S. Department of Labor, Bureau of Labor Statistics.

Copeland, Adam, Wendy Dunn, and George Hall (2005). "Prices, Production, and Inventories over the Automotive Model Year," Finance and Economics Discussion Series 2005-25. Washington: Board of Governors of the Federal Reserve System, May.

Diewert, W. Erwin (1987). "Index Numbers," in John Eatwell, Murray Milgate, and Peter Newman, eds., The New Palgrave: A Dictionary of Economics, vol. 2. New York: Stockton Press, pp. 767-80.

Diewert, W. Erwin (1998). "High Inflation, Seasonal Commodities and Annual Index Numbers," Macroeconomic Dynamics, vol. 2 (December), pp. 456-71.

Diewert, W. Erwin (1999). "Index Number Approaches to Seasonal Adjustment," Macroeconomic Dynamics, vol. 3 (March), pp. 48-68. 
Diewert, W. Erwin (2005). "Issues in the Measurement of Capital Services, Depreciation, Asset Price Changes, and Interest Rates," in Carol Corrado, John Haltiwanger, and Daniel Sichel, eds., Measuring Capital in the New Economy. Chicago: University of Chicago Press.

Feenstra, Robert C. (1994). "New Product Varieties and the Measurement of International Prices," American Economic Review, vol. 84 (March), pp. 157-77.

Gordon, Robert J. (1990). The Measurement of Durable Goods Prices. Chicago: University of Chicago Press.

Griliches, Z. (1961). "Hedonic Price Index for Automobiles: An Econometric Analysis of Quality Change," in The Price Statistics of the Federal Government, General Series 73. New York: National Bureau of Economic Research, pp. 137-96. Reprinted in Z. Griliches (1971), ed., Price Indexes and Quality Change. Cambridge, Mass.: Harvard University Press.

Houthakker, Hendrik S., and Lester D. Taylor (1970). Consumer Demand in the United States: Analyses and Projections. Cambridge, Mass.: Harvard University Press.

J.D. Power and Associates (2003). PIN Explorer Glossary, mimeo, Power Information Network.

Pashigian, Peter B., Brian Bowen, and Eric Gould (1995). "Fashion, Styling, and the WithinSeason Decline in Automobile Prices," Journal of Law and Economics, vol. 38 (October), pp. 281-309.

Triplett, Jack E. (1969). “Automobiles and Hedonic Quality Measurement,” Journal of Political Economy, vol. 77 (May-June), pp. 408-17. 
Table 1. Definition of Selected Variables in PIN Explorer

\begin{tabular}{ll}
\hline Variable & Definition \\
\hline Vehicle price & The price that a customer pays for a vehicle and for factory and dealer- \\
& installed accessories and options, adjusted for the trade-in allowance. \\
& (The trade-in allowance is the difference, if any, between the amounts a \\
& dealer allows a customer for a trade-in and the wholesale market-value of \\
the trade-in.) The vehicle price excludes the price of aftermarket options, \\
fees, taxes, or service contracts. \\
The price after manufacturer-to-consumer rebates. The customer cash \\
rebate, the cash amount given to the customer, is subtracted from vehicle \\
prich rebate \\
price \\
Thterest rate \\
(APR/IRR rate) \\
leased vehicle. For finance transactions, the APR is as defined in the \\
Federal Reserve Board's Regulation Z. For leased transactions, PIN \\
calculates an internal rate of return (IRR) that is comparable to the APR. \\
The number of months that a customer will make finance or lease \\
payments on a vehicle. \\
The portion of the total purchase price (including the cost of finance and \\
insurance products) that is funded by a lender or lessor. Applies only to \\
finance and lease transactions. \\
The age of the customer at the time of purchase or lease.
\end{tabular}

Note: Includes purchased and leased vehicles.

Source: PIN Explorer Glossary, J.D. Power and Associates (2003). 
Table 2. Interest Rates on New Vehicle Loans and the Average Age and Income of Buyers

\begin{tabular}{lcccccc}
\hline & \multicolumn{5}{c}{ Age of respondent (years) } \\
\cline { 2 - 7 } Mean & $21-29$ & $30-39$ & $40-49$ & $50-59$ & $60-69$ & 70 and over \\
\hline Interest rate (percent) & 11.2 & 10.2 & 9.4 & 9.1 & 8.9 & 7.2 \\
Total household income & 48 & 108 & 142 & 603 & 494 & 71 \\
Household wage income $^{1}$ & 45 & 97 & 81 & 101 & 72 & 21 \\
\hline
\end{tabular}

Note: In thousands of current dollars; reflects income in 2000; number of observations is 686.

Source: Survey of Consumer Finances, 2001, Board of Governors of the Federal Reserve System. 
Table 3. Factors Affecting Interest Rates on New Vehicle Loans, Selected Results, 1999-2001

\begin{tabular}{|c|c|c|c|c|}
\hline Dependent variable: interest rate on new vehicle loans & (1) & $(2)$ & (3) & (4) \\
\hline$\overline{\text { Age }}$ & $\begin{array}{c}-0.05 \\
(0.01)\end{array}$ & $\begin{array}{c}-0.02 \\
(0.01)\end{array}$ & $\begin{array}{c}-0.02 \\
(0.01)\end{array}$ & $\begin{array}{l}-0.05 \\
(0.01)\end{array}$ \\
\hline Annual household income & & $\begin{array}{l}-0.08 \\
(0.50)\end{array}$ & & \\
\hline Annual wages and salaries & & & $\begin{array}{c}-0.11 \\
(0.38)\end{array}$ & \\
\hline Home ownership & & $\begin{array}{l}-2.32 \\
(0.16)\end{array}$ & $\begin{array}{l}-2.32 \\
(0.16)\end{array}$ & \\
\hline Educational attainment & & $\begin{array}{l}-1.15 \\
(0.18)\end{array}$ & $\begin{array}{l}-1.18 \\
(0.18)\end{array}$ & \\
\hline \multicolumn{5}{|l|}{ Lending source: } \\
\hline Captive finance companies & & & & $\begin{array}{l}-1.28 \\
(0.52)\end{array}$ \\
\hline Credit unions & & & & $\begin{array}{l}-1.09 \\
(0.45)\end{array}$ \\
\hline Finance companies & & & & $\begin{array}{r}1.53 \\
(0.41) \\
\end{array}$ \\
\hline
\end{tabular}

Note: Observations total 685. The data are unweighted. Each regression also included a variable to control for cyclical movements in interest rates. Regressions in columns 2 and 3 contained additional variables: number in household, race of respondent, gender of respondent, and type of vehicle purchased (automobile or light truck). The numbers in parentheses are standard errors.

Source: Survey of Consumer Finances, 2001, Board of Governors of the Federal Reserve System. 
Table 4. Examples of Model-Level Detail and Nomenclature in PIN Explorer

\begin{tabular}{ccccc}
\hline Manufacturer & Nameplate & Model & Trim level & Model year \\
\hline General Motors & Buick & LeSabre & LeSabre Limited & 2001 \\
BMW Group & BMW & 325xi & n.a. & 2003 \\
Ford & Mercury & Sable & Sable GS & 2000 \\
DaimlerChrysler & Mercedes-Benz & ML320 & n.a. & 1998 \\
\hline
\end{tabular}

Source: J.D. Power and Associates.

n.a. Not available. 
Table 5. Average Value of Consumer Vehicle Incentives and Prices (dollars), 1999-2003

\begin{tabular}{c|c|ccccc}
\hline & Average & 1999 & 2000 & 2001 & 2002 & 2003 \\
\hline Value of incentives & 1,421 & 803 & 1,111 & 1,398 & 1,627 & 2,168 \\
Cash rebates & 689 & 339 & 402 & 508 & 842 & 1,352 \\
Interest subvention & 733 & 464 & 709 & 890 & 785 & 816 \\
Actual price & 24,024 & 23,312 & 23,540 & 23,926 & 24,469 & 24,873 \\
Car & 22,318 & 21,853 & 22,147 & 22,268 & 22,665 & 22,655 \\
Truck & 25,619 & 24,740 & 25,031 & 25,502 & 26,074 & 26,749 \\
Price after cash rebate & 24,757 & 23,776 & 24,249 & 24,816 & 25,254 & 25,689 \\
Car & 22,936 & 22,275 & 22,742 & 22,998 & 23,314 & 23,351 \\
Truck & 26,460 & 25,256 & 25,868 & 26,547 & 26,978 & 27,653 \\
Price before incentives & 25,445 & 24,115 & 24,651 & 25,324 & 26,096 & 27,041 \\
Car & 23,491 & 22,633 & 23,089 & 23,421 & 23,937 & 24,376 \\
Truck & 27,268 & 25,565 & 26,332 & 27,149 & 28,015 & 29,278 \\
\hline Memo: & & & & & & 45.3 \\
Customer age (years) & 44.4 & 43.1 & 43.4 & 44.5 & 45.2 & 45.7 \\
Loan term (months) & 53.4 & 49.9 & 51.1 & 53.2 & 55.2 & 57.4 \\
Interest rate (percent) & 6.9 & 7.8 & 8.2 & 6.9 & 6.3 & 5.4 \\
Amount financed & 23,508 & 22,162 & 22,803 & 23,339 & 24,232 & 25,004 \\
\hline
\end{tabular}

Note: All items are sales-weighted.

Source: Authors' estimates based on information from J.D. Power and Associates’ PIN Explorer database. 
Table 6. PIN Models by Model Year, 1998-2004

\begin{tabular}{|c|c|c|c|c|c|c|}
\hline \multirow[b]{2}{*}{$\begin{array}{c}\text { Model } \\
\text { year }\end{array}$} & \multirow{2}{*}{$\begin{array}{c}\text { Total } \\
\text { number } \\
\text { models }\end{array}$} & \multirow[b]{2}{*}{$\begin{array}{c}\text { New } \\
\text { models }\end{array}$} & \multicolumn{3}{|c|}{ Continuing models } & \multirow{2}{*}{$\begin{array}{c}\text { Memo: Ward's } \\
\text { AutoInfo } \\
\text { Databank } \\
\end{array}$} \\
\hline & & & Total & $\begin{array}{c}\text { Major } \\
\text { re-designs }\end{array}$ & $\begin{array}{l}\text { New } \\
\text { trims }^{2}\end{array}$ & \\
\hline 1998 & 259 & 21 & 238 & 16 & n.a. & 256 \\
\hline 1999 & 273 & 28 & 245 & 18 & n.a. & 253 \\
\hline 2000 & 280 & 35 & 245 & 18 & 53 & 266 \\
\hline 2001 & 306 & 59 & 247 & 17 & 74 & 276 \\
\hline 2002 & 322 & 40 & 282 & 13 & 79 & 279 \\
\hline 2003 & 324 & 42 & 282 & 15 & 70 & 295 \\
\hline 2004 & 335 & 46 & 289 & 15 & 58 & 304 \\
\hline Total, all years & 506 & 271 & - & 112 & - & 400 \\
\hline
\end{tabular}

${ }^{1}$ The number of newly introduced PIN models for the 1998 model year was derived from Ward's and Internet sources. The figures for the 1999 and 2000 model years were derived from PIN, Ward's, and Internet sources; all other years are based on new models in PIN. The pure PIN numbers for 1999 and 2000 (33 and 38, respectively) are somewhat larger than the actual number of new model introductions, whereas differences in other years are very small.

${ }^{2}$ Excludes new trims associated with major redesigns.

Source: J.D. Power and Associates’ Power Information Network (PIN) Explorer database (model years 2001 to 2004) and PIN data archives (model years 1998 to 2000). The statistics on redesigns were compiled using data on platform changes from Ward's and Internet sources (www.intellichoice.com and www.edmunds.com). 
Table 7. Number of Continuing Models by Model Year, average monthly rate per quarter, 1998:Q4 - 2003:Q4

\begin{tabular}{|c|c|c|c|c|c|c|c|c|c|c|c|c|c|c|c|c|c|c|c|c|c|}
\hline Model Year & 98Q4 & 99Q1 & 99Q2 & 99Q3 & 99Q4 & 00Q1 & 00Q2 & 00Q3 & 00Q4 & 01Q1 & 01Q2 & 01Q3 & 01Q4 & 02Q1 & 02Q2 & 02Q3 & 02Q4 & 03Q1 & 03Q2 & 03Q3 & 03Q4 \\
\hline 1998 & 176 & 127 & 53 & 13 & & & & & & & & & & & & & & & & & \\
\hline 1999 & 200 & 246 & 248 & 238 & 199 & 149 & 73 & 18 & & & & & & & & & & & & & \\
\hline 2000 & & 6 & 14 & 64 & 220 & 252 & 259 & 249 & 211 & 163 & 100 & 40 & 9 & 3 & 2 & 2 & 1 & & & & \\
\hline 2001 & & & & & & 4 & 20 & 87 & 251 & 278 & 285 & 273 & 250 & 173 & 96 & 31 & 2 & & & & \\
\hline 2002 & & & & & & & & & & & 13 & 80 & 274 & 301 & 303 & 289 & 244 & 165 & 98 & 39 & 6 \\
\hline 2003 & & & & & & & & & & & & & & 4 & 18 & 85 & 261 & 299 & 303 & 293 & 262 \\
\hline 2004 & & & & & & & & & & & & & & & & & & 3 & 25 & 102 & 274 \\
\hline Total Continuing & 375 & 378 & 315 & 316 & 420 & 405 & 352 & 354 & 462 & 442 & 398 & 393 & 533 & 480 & 418 & 406 & 509 & 467 & 427 & 434 & 542 \\
\hline Entering & 30 & 4 & 5 & 57 & 19 & 9 & 7 & 64 & 17 & 7 & 7 & 71 & 21 & 5 & 9 & 67 & 20 & 9 & 12 & 63 & 25 \\
\hline Exiting & 16 & 17 & 26 & 16 & 17 & 17 & 29 & 19 & 20 & 16 & 23 & 25 & 18 & 30 & 28 & 25 & 25 & 26 & 26 & 23 & 21 \\
\hline Total marketed & 406 & 383 & 320 & 373 & 438 & 414 & 359 & 418 & 479 & 449 & 404 & 464 & 554 & 485 & 427 & 474 & 529 & 476 & 439 & 497 & 567 \\
\hline
\end{tabular}

Note: Components may not sum to totals because of independent rounding. Exiting models are counted in month $\mathrm{t}+1$-that is, the period in which a match cannot be made. Total marketed is the sum of continuing plus entering models.

Source: Authors' data set constructed from J.D. Power and Associates' PIN Explorer Database. In the authors' data set, PIN transactions for a model in a month that preceded or trailed the primary selling period for the model by more than one month were excluded. 
Table 8. Model-year Price Indexes by Price Concept and Nameplate (percent change over the model year, annualized)

\begin{tabular}{|c|c|c|c|c|c|c|}
\hline & \multirow[b]{2}{*}{ Average } & \multicolumn{5}{|c|}{ Model year of index } \\
\hline & & 1999 & 2000 & 2001 & 2002 & 2003 \\
\hline Actual price & -6.1 & -4.1 & -5.2 & -6.8 & -6.0 & -8.4 \\
\hline Big Three nameplates & -7.0 & -4.8 & -6.8 & -8.3 & -5.5 & -9.4 \\
\hline Large Japanese nameplates & -5.2 & -2.7 & -3.6 & -5.8 & -6.7 & -7.0 \\
\hline Other nameplates & -5.2 & -4.4 & -3.1 & -4.6 & -6.2 & -7.6 \\
\hline Price after cash rebate & -4.7 & -4.2 & -3.3 & -3.6 & -4.4 & -7.9 \\
\hline Big Three nameplates & -5.2 & -4.9 & -3.6 & -3.9 & -4.4 & -9.1 \\
\hline Large Japanese nameplates & -4.0 & -2.2 & -3.6 & -4.0 & -4.6 & -5.6 \\
\hline Other nameplates & -4.8 & -4.8 & -3.1 & -3.5 & -5.2 & -7.6 \\
\hline Price before incentives & -2.4 & -2.5 & -1.9 & -2.7 & -2.3 & -2.7 \\
\hline Big Three nameplates & -1.6 & -2.5 & -1.4 & -2.4 & -1.0 & -0.9 \\
\hline Large Japanese nameplates & -3.2 & -1.5 & -3.1 & -3.2 & -3.9 & -4.3 \\
\hline Other nameplates & -3.8 & -3.9 & -2.5 & -2.8 & -4.5 & -5.2 \\
\hline
\end{tabular}

Effect of incentives (percentage points)

\begin{tabular}{|c|c|c|c|c|c|c|}
\hline Both incentives (actual price less price before incentives) & 3.7 & 1.7 & 3.3 & 4.1 & 3.7 & 5.7 \\
\hline Big Three nameplates & 5.4 & 2.3 & 5.4 & 5.9 & 4.5 & 8.5 \\
\hline Large Japanese nameplates & 2.0 & 1.2 & 0.4 & 2.5 & 2.8 & 2.8 \\
\hline Other nameplates & 1.4 & 0.5 & 0.6 & 1.8 & 1.7 & 2.5 \\
\hline Cash rebate (price after rebate less price before) & 2.3 & 1.8 & 1.4 & 0.9 & 2.1 & 5.2 \\
\hline Big Three nameplates & 3.6 & 2.5 & 2.2 & 1.5 & 3.5 & 8.3 \\
\hline Large Japanese nameplates & 0.8 & 0.7 & 0.4 & 0.7 & 0.7 & 1.3 \\
\hline Other nameplates & 1.1 & 0.9 & 0.6 & 0.6 & 0.7 & 2.4 \\
\hline Interest subvention (actual price less price after rebate) & 1.4 & 0.1 & 1.9 & 3.2 & 1.6 & 0.5 \\
\hline Big Three nameplates & 1.8 & 0.2 & 3.2 & 4.4 & 1.1 & 0.3 \\
\hline Large Japanese nameplates & 1.2 & 0.5 & 0.0 & 1.8 & 2.1 & 1.4 \\
\hline Other nameplates & 0.4 & 0.4 & 0.0 & 1.2 & 1.0 & 0.0 \\
\hline
\end{tabular}

Note: The changes are from the third quarter of the introductory year to the fourth quarter of the following year. The Big Three refers to General Motors, Ford, and Chrysler.

Source: Authors' estimates based on information from J.D. Power and Associates’ PIN Explorer database. 
Table 9. Model-year Price Indexes by Market Segment (percent change over the model year, annualized)

\begin{tabular}{c|c|ccccc}
\hline & & \multicolumn{7}{|c}{ Model year of index } \\
\cline { 3 - 6 } & \multirow{2}{*}{ Average } & 1999 & 2000 & 2001 & 2002 & 2003 \\
\cline { 2 - 6 } Actual price & -6.1 & -4.1 & -5.2 & -6.8 & -6.0 & -8.4 \\
Car & -6.3 & -4.2 & -4.9 & -6.6 & -7.3 & -8.7 \\
Compact & -6.5 & -5.2 & -4.6 & -5.6 & -7.9 & -9.0 \\
Mid-size & -6.5 & -3.5 & -5.3 & -7.3 & -7.2 & -9.1 \\
Full-size & -8.9 & -6.7 & -8.5 & -10.6 & -9.4 & -9.5 \\
Luxury & -5.6 & -4.1 & -3.9 & -5.3 & -7.1 & -7.7 \\
Sports & -6.6 & -5.0 & -4.7 & -8.3 & -6.3 & -8.9 \\
Truck & -5.9 & -4.0 & -5.5 & -6.9 & -4.9 & -8.2 \\
Pickup & -6.0 & -6.1 & -4.6 & -6.4 & -5.8 & -7.2 \\
SUV & -5.7 & -2.7 & -6.1 & -6.9 & -4.9 & -7.9 \\
Van & -6.7 & -5.4 & -6.3 & -7.3 & -4.3 & -10.0 \\
\hline
\end{tabular}

Effect of incentives (percentage points)

\begin{tabular}{c|l|lllll}
\hline Both incentives & 3.7 & 1.7 & 3.3 & 4.1 & 3.7 & 5.7 \\
Car & 3.1 & 1.8 & 2.8 & 3.5 & 3.1 & 4.4 \\
Compact & 4.2 & 2.7 & 2.5 & 3.8 & 4.8 & 7.3 \\
Mid-size & 3.8 & 2.9 & 3.5 & 4.5 & 2.9 & 5.2 \\
Full-size & 7.3 & 4.6 & 8.7 & 8.8 & 6.1 & 8.2 \\
Luxury & 0.6 & 0.8 & 0.3 & 1.2 & 1.6 & 0.8 \\
\cline { 2 - 2 } Sports & 2.7 & 0.9 & 2.3 & 3.8 & 2.5 & 3.8 \\
\cline { 2 - 2 } Truck & 4.1 & 1.5 & 3.9 & 4.4 & 4.0 & 6.7 \\
Pickup & 4.9 & 2.0 & 3.7 & 5.0 & 5.2 & 8.7 \\
SUV & 3.9 & 1.3 & 3.9 & 4.3 & 4.2 & 5.7 \\
Van & 3.7 & 1.5 & 4.6 & 3.3 & 1.5 & 7.4 \\
\hline
\end{tabular}

Note: The changes are from the third quarter of the introductory year to the fourth quarter of the following year. SUV refers to sport utility vehicle.

Source: Authors' estimates based on information from J.D. Power and Associates' PIN Explorer database. 
Table 10. Model-year Price Indexes by Models Treated as New (percent change over the model year, annualized)

\begin{tabular}{l|c|ccccc}
\hline & \multirow{5}{*}{} & \multicolumn{5}{c}{ Model year of index } \\
\cline { 3 - 6 } & Average & 1999 & 2000 & 2001 & 2002 & 2003 \\
\hline Actual price & -6.1 & -4.1 & -5.2 & -6.8 & -6 & -8.4 \\
Entering models, redesigns & -6.3 & -3.2 & -4.4 & -6.5 & -7.5 & -9.7 \\
Other models & -6.1 & -4.3 & -5.3 & -6.9 & -5.8 & -8.3 \\
\hline \multicolumn{7}{c}{ Effect of incentives (percentage points) } \\
\hline Both incentives & 3.7 & 1.7 & 3.3 & 4.1 & 3.7 & 5.7 \\
Entering models, redesigns & 2.8 & 1.5 & 1.8 & 2.8 & 3.9 & 3.9 \\
Other models & 3.9 & 1.7 & 3.6 & 4.4 & 3.7 & 6.2 \\
\hline
\end{tabular}

Note: The changes are from the third quarter of the introductory year to the fourth quarter of the following year.

Source: Authors' estimates based on information from J.D. Power and Associates' PIN Explorer database. 
Table 11. Consumer Vehicle Price Indexes, by Price Concept and Models Treated as New (twelve month percent change, December to December)

\begin{tabular}{l|c|ccccc}
\hline & Average & 1999 & 2000 & 2001 & 2002 & 2003 \\
\hline Actual price & & & & & & \\
$\quad$ Entering models, redesigns & -1.2 & 1.3 & -0.9 & -2.6 & -2.2 & -1.5 \\
$\quad \begin{array}{l}\text { Entering models, redesigns, new trims } \\
\text { All models }\end{array}$ & -3.3 & -1.3 & -3.0 & -4.2 & -4.2 & -3.9 \\
$\quad-5.9$ & -2.9 & -6.1 & -6.2 & -6.6 & -7.7 \\
Price after cash rebate & & & & & & \\
$\quad$ Entering models, redesigns & -0.7 & 0.9 & 0.6 & -0.1 & -2.4 & -2.4 \\
$\quad$ Entering models, redesigns, new trims & -2.6 & -1.3 & -1.3 & -1.6 & -3.8 & -4.7 \\
$\quad$ All models & -4.9 & -3.2 & -3.9 & -3.5 & -5.7 & -8.0 \\
Price before incentives & & & & & & \\
$\quad$ Entering models, redesigns & & & & & \\
$\quad$ Entering models, redesigns, new trims & -0.7 & -0.1 & 0.0 & -1.1 & -1.2 & -1.0 \\
$\quad$ All models & -2.3 & -1.5 & -2.1 & -2.4 & -2.5 & -3.1 \\
\hline
\end{tabular}

Percent change in average selling price

\begin{tabular}{|c|c|c|c|c|c|c|}
\hline Actual price & 2.5 & 3.8 & 0.4 & 1.0 & 2.5 & 4.9 \\
\hline Price after cash rebate & 2.6 & 3.5 & 1.4 & 2.7 & 1.9 & 3.7 \\
\hline Price before incentives & 3.5 & 3.7 & 1.8 & 2.5 & 4.1 & 5.4 \\
\hline \multicolumn{7}{|c|}{ Implied quality change $^{1}$} \\
\hline \multicolumn{7}{|l|}{ Actual price } \\
\hline Entering models, redesigns & 3.7 & 2.6 & 1.4 & 3.6 & 4.7 & 6.4 \\
\hline Entering models, redesigns, new trims & 5.8 & 5.1 & 3.5 & 5.2 & 6.7 & 8.8 \\
\hline All models & 8.4 & 6.8 & 6.6 & 7.2 & 9.1 & 12.6 \\
\hline \multicolumn{7}{|l|}{ Price after cash rebate } \\
\hline Entering models, redesigns & 3.3 & 2.6 & 0.8 & 2.8 & 4.3 & 6.1 \\
\hline Entering models, redesigns, new trims & 5.2 & 4.8 & 2.7 & 4.4 & 5.8 & 8.3 \\
\hline All models & 7.5 & 6.7 & 5.3 & 6.3 & 7.6 & 11.7 \\
\hline \multicolumn{7}{|l|}{ Price before incentives } \\
\hline Entering models, redesigns & 2.7 & 2.2 & 0.2 & 2.3 & 4.0 & 4.8 \\
\hline Entering models, redesigns, new trims & 4.2 & 3.8 & 1.8 & 3.6 & 5.2 & 6.4 \\
\hline All models & 5.8 & 5.1 & 3.9 & 4.8 & 6.6 & 8.5 \\
\hline CPI for new vehicles & -0.9 & -0.5 & 0.0 & -0.1 & -2.0 & -1.9 \\
\hline
\end{tabular}

${ }^{1}$ Percent change in average selling price less percent change in price index.

Source: Authors' estimates based on information from J.D. Power and Associates' PIN Explorer Database. 


\section{Value of Incentives}

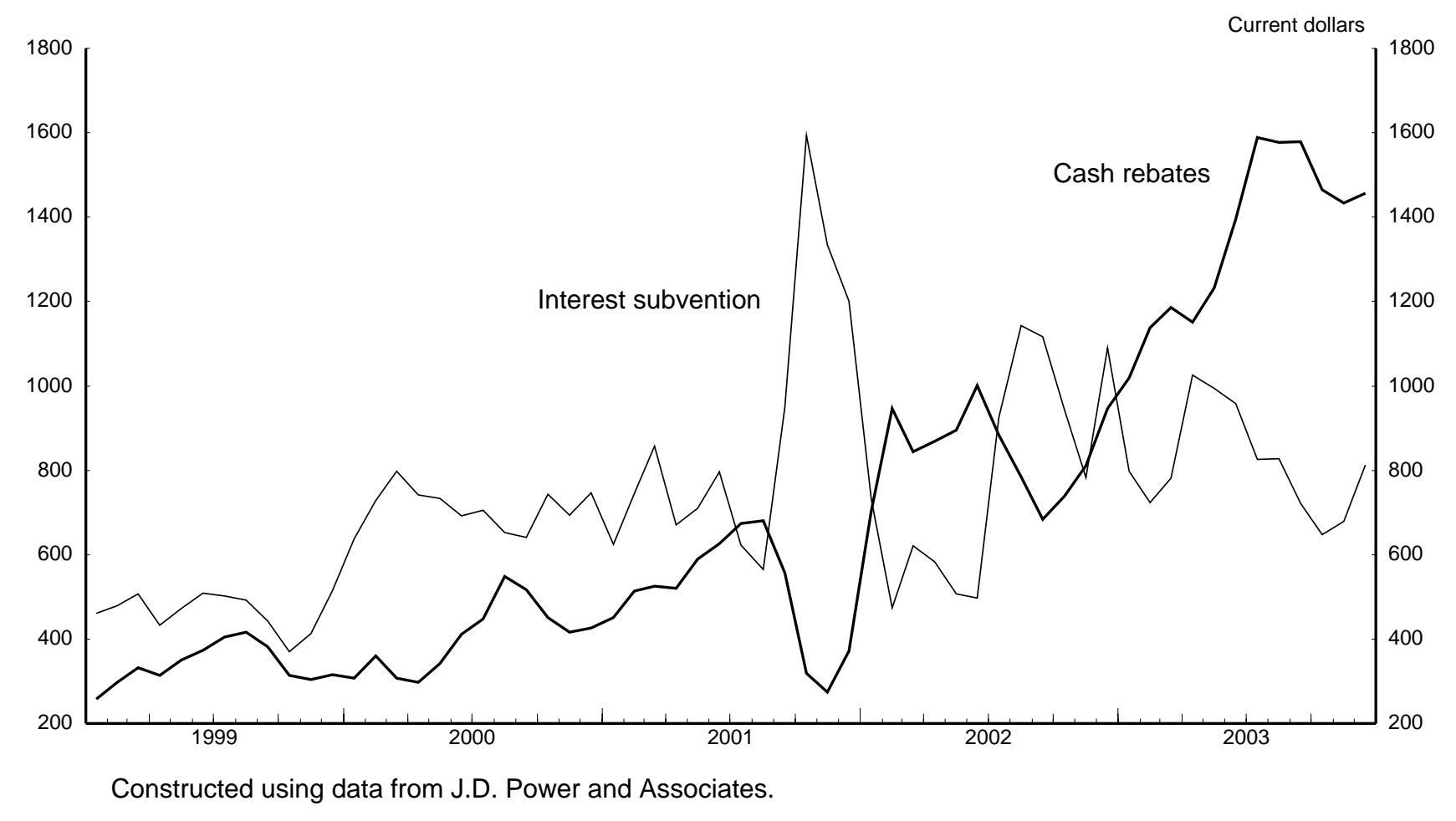




\section{Sales Penetration of Incentives}

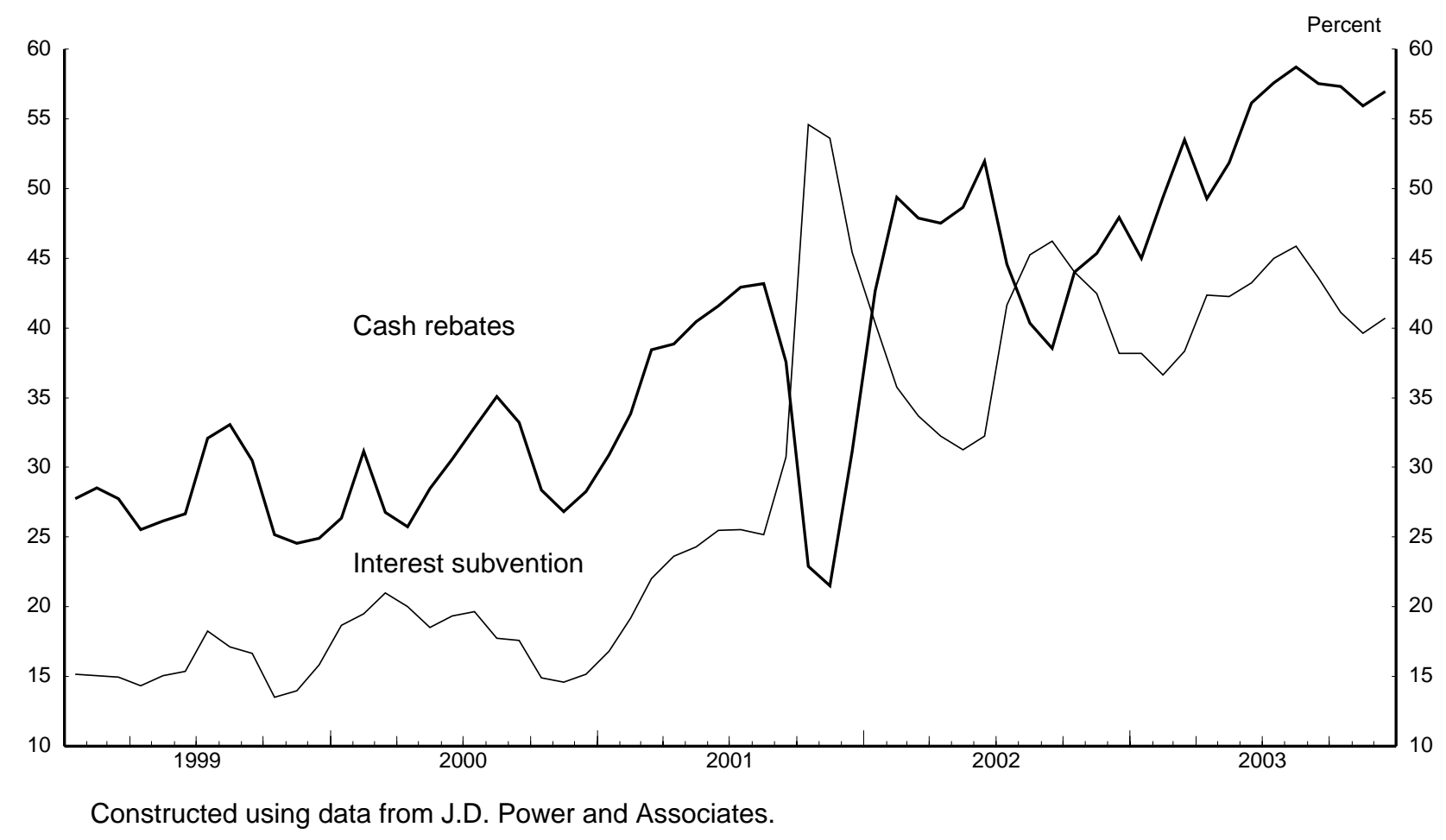


Chart 3. Count of Models Sold by Month, 1995-2004

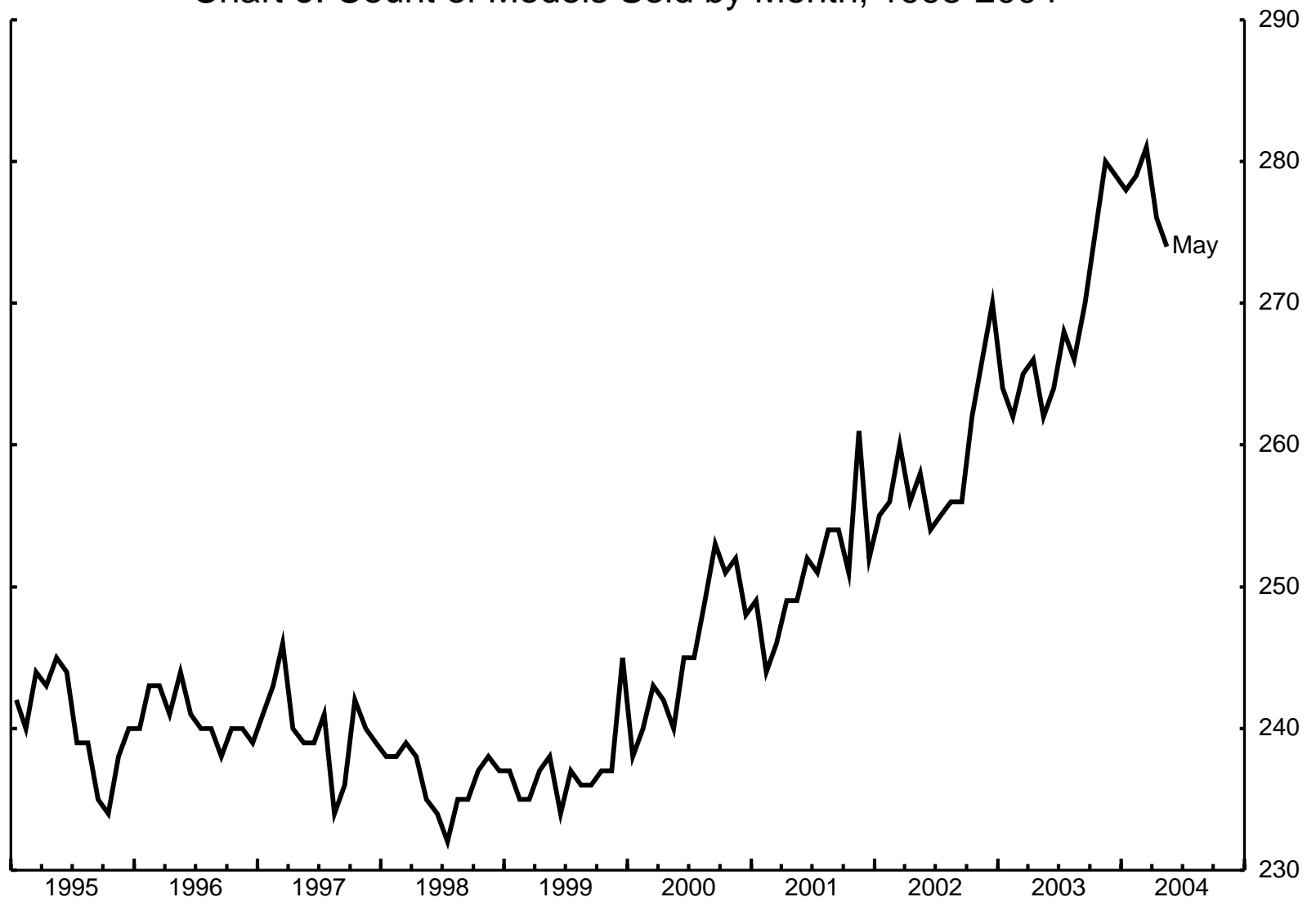

Source. Ward's Communications. 


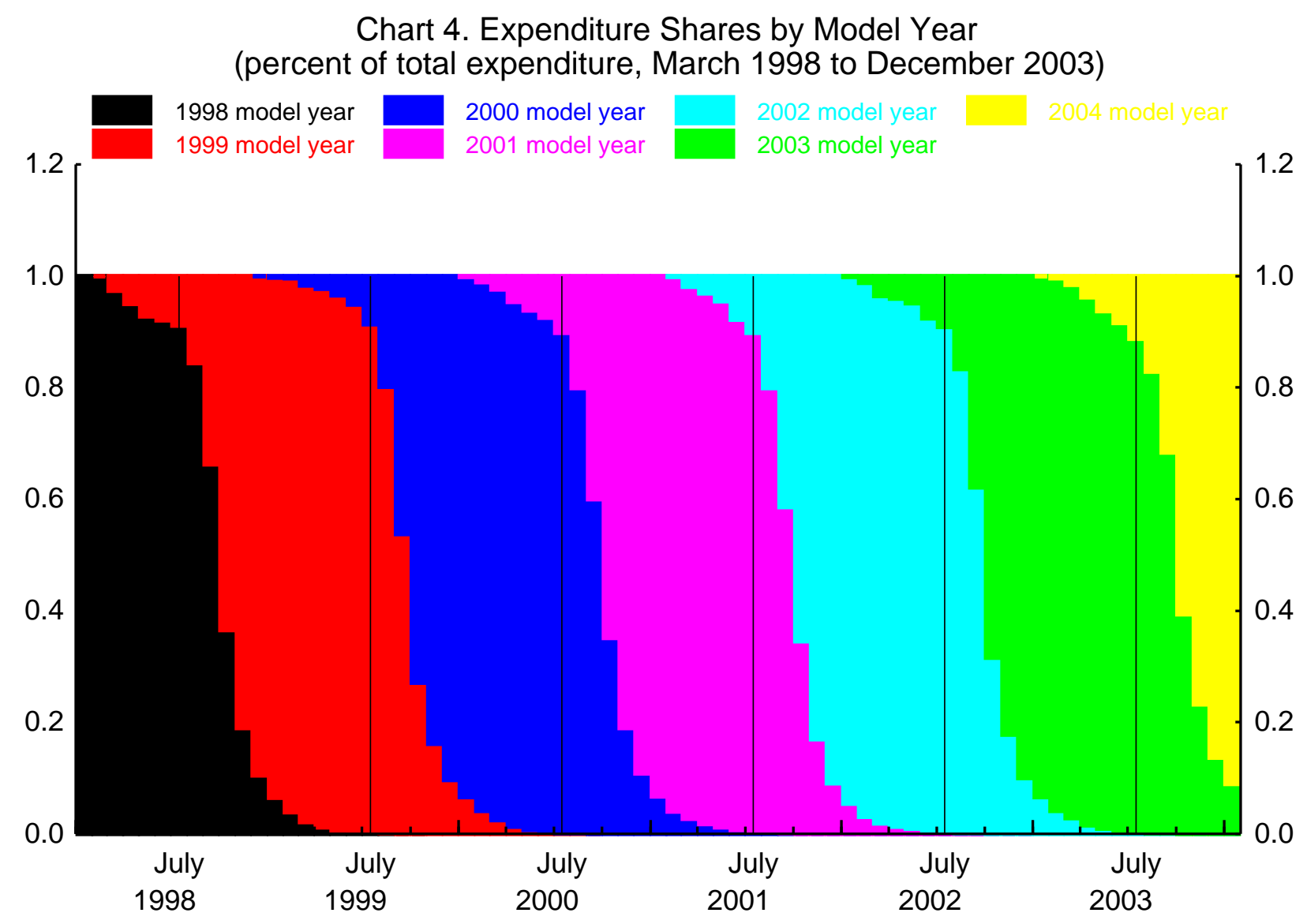

Constructed using data from J.D. Power and Associates. 
Chart 5. Matched-model Price Indexes by Model Year

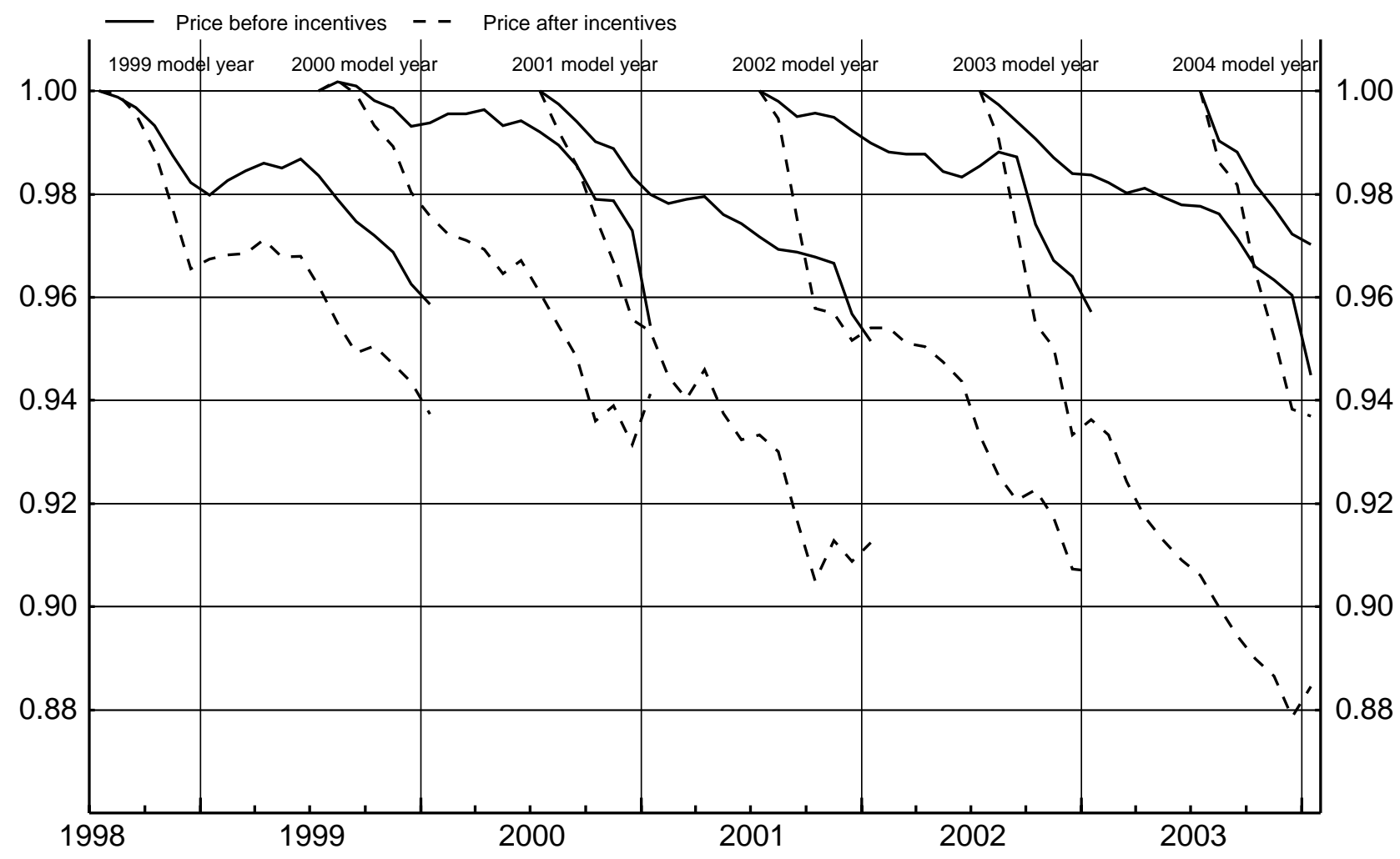

Constructed using data from J.D. Power and Associates. 